\title{
The need for power, need for influence, sense of power, and directiveness in female and male superiors and subordinates
}

\author{
Dagna Kocur ${ }^{B, C, E, F}$, Eugenia Mandal ${ }^{A, D, E, F}$ \\ Institute of Psychology, Department of Social and Environmental Psychology, University of Silesia, Katowice, Poland
}

BACKGROUND

The purpose of the study was to examine the phenomenon of power within an organisation from the vantage point of gender, the occupied position, earnings, and the number of subordinates.

PARTICIPANTS AND PROCEDURE

The sample group comprised 107 female and 98 male participants. The mean age was 42.14 years $(S D=11.73)$. The study covered 100 superiors and 105 subordinates. The research tools were: the Need for Power and Influence Questionnaire (Bennett, 1988), the Personal Sense of Power Scale (Anderson, John, \& Keltner, 2012), and the Directiveness Scale SD (Ray, 1976).

\section{RESULTS}

The superiors scored significantly higher on the need for power, need for influence, and directiveness. They also scored higher in terms of the need for power in relations with other people, with colleagues, and in superior-subordinate relations. The number of male leaders was conspicuously greater than the number of female leaders. Furthermore, women had fewer subordinates than men and earned less than men. Female participants scored lower on the sense of power and the need for power scales.

\section{CONCLUSIONS}

Occupying either an executive or subordinate position differentiates between women and men in terms of sense of power in interpersonal relationships. The findings on sense of power in the professional context may be applied in organisational psychology in order to increase employees' competence and qualifications.

\section{KEY WORDS}

power; need for power; sense of power; gender; superiors; subordinates

Corresponding Author - Dagna Kocur, Ph.D., Institute of Psychology, Department of Social and Environmental

Psychology, University of Silesia, Katowice, Poland, e-mail: dagna.kocur@us.edu.pl

authors' contribution - A: Study design - B: Data collection - C: Statistical analysis - D: Data interpretation .

E: Manuscript preparation · F: Literature search · G: Funds collection

to Cite this ARTICLE - Kocur, D., \& Mandal, E. (2018). The need for power, need for influence, sense of power,

and directiveness in female and male superiors and subordinates. Current Issues in Personality Psychology, 6(1),

$47-56$.

RECEIVED 29.04.2017 · REVIEWED 04.06.2017 · ACCEPTED 07.11.2017 • PUBLISHED 18.12.2017 


\section{BACKGROUND}

The situation in which a person occupies a managerial position in the professional hierarchy is a specific one and may affect this person's general functioning patterns. Empirical studies have confirmed the consequences arising from holding a superior position on the following levels: cognitive (Fiske, 1993), behavioural (Galinsky, Gruenfeld, \& Magge, 2003), emotional (Wojciszke \& Strużyńska-Kujałowicz, 2007), and social (Galinsky et al., 2006, 2008). Interestingly, leadership positions are most frequently held by people with specific personality and disposition traits, such as intelligence, stereotypical masculinity, extraversion, and great adaptation skills (Lord, de Vader, \& Alliger, 1986). Hence, a question may arise, of whether people in managerial positions differ from one another also in terms of the need for power and influence and the sense of power itself.

According to French and Raven, power is a special relationship between two people, which is a source of power for one over the other (French \& Raven, 1959). Thibaut and Kelly (1959) perceive power as the ability to influence the type and the quality of other people's behaviour as well as the control of resources, which enables those in possession of power to obtain the potential necessary to exert influence. In psychology, a number of researchers treat power and influence as interchangeable constructs; however, a more in-depth analysis makes a case to draw a distinction between the two. Minton (1972) argues that social influence is a potential that enables a person to affect other people's actions, whereas power is the ability to influence those actions. According to Wendell Bell (1975), power consists of the ability to employ positive and negative sanctions (threats and promises, among others), while influence occurs in communications aimed at changing other people's behaviours in the absence of those sanctions. Joel Bennett (1988) differentiates between the need for power (nPower) and the need for influence (nInfluence), implementing certain psychometric tests. The writer argues that nPower consists of striving to gain a certain position, whereas nInfluence is the need to persuade others and exert an impact on them (Bennett, 1988).

Research and analyses conducted by Joel Bennett (1988) have proven that individuals differ with respect to their need and striving for power as well as when it comes to their need for power. Power-motivated individuals crave a position that will enable them to exercise their power for their own sake for instance to derive satisfaction from dealing with people who depend on them. Individuals motivated by the need to exert impact strive to influence events and other people. People who are characterised by a considerable need for influence may also exhibit a great need for power. Should they not hold power, they may also be satisfied by influencing others, utilising means other than pressure, coercion, or directions. The need for power and need for influence are therefore conceptually distinct constructs that are not necessarily correlated (Bennett, 1988).

The Personal Sense of Power is a perception of one's own ability to influence another person or other people (Anderson, John, \& Keltner, 2012). It is vital to emphasise that in this case, power is defined as the ability to affect other people. Personal sense of power may differ substantially depending on the kind of interpersonal relationship. Studies have shown that it is greater in relations with friends than with parents. Personal sense of power arises not only from objective factors of a social nature that create special conditions for individuals who are in possession of greater resources. Personal variables also play an important role in determining how powerful a person considers him or herself to be. Studies by Cameron Anderson, Oliver John, and Dacher Keltner (2012) show individual differences in personal sense of power, even when it comes to people in similar social positions. Individuals who hold similar social positions but differ in terms of their personal sense of power exhibited, among others, dissimilar extraversion levels.

The Euro-American culture tends to attribute power to males. The existence of a glass ceiling - an invisible barrier that prevents women from climbing the career ladder and gaining managerial positions - has been proven by several studies and analyses (cf. Mandal, 1995; Mandal, 2007; Brannon, 2002; Wojciszke, 2002; Titkow, 2003). In 2017 in the USA there were 21 women per 100 senators; out of 435 members of the House of Representatives, 84 were women. In Poland, women occupy less than $20.00 \%$ of the seats in Parliament. The differences between the two sexes are reflected in earnings: in 2014 men earned on average 4600 PLN while women - 3600 PLN (Polish nationwide compensation survey by Sedlak \& Sedlak, 2014). Every fourth male employee earned 7700 PLN or more, while every fourth female employee received 5700 PLN or more. Women are more likely to have low-paying jobs, such as teacher, nurse, or cleaner. Typically, male professions, such as programmer or machine operator are, on the other hand, better paid (Saltzman, 1991; Brannon, 2002).

There are numerous differences between women and men in the professional context, and they exist on multiple levels. However, research conducted by Eugenia Mandal (2007) showed that the differences between the sexes within an organisation are less significant than the differences between superiors and subordinates. The research carried out in a large professional organisation showed more differences between the groups of superiors and subordinates than between women and men. Female superiors 
were more masculine than female subordinates, and had a greater internal locus of control and a higher level of social competence, especially in terms of assertiveness and social exposure. Those differences were not observed when comparing women and men in leadership roles. The findings emphasise the greater importance of the professional role, as a superior or a subordinate, rather than the differences between genders.

Empirical studies prove how women and men vary in terms of the need for power and sense of power. A study by Bennett (1998) revealed lower female scores in terms of the need for power and lower resistance to taking orders. In several studies women also scored lower than men on directiveness (Ray, 1976; Brzozowski, 1997). There may be two reasons for this situation. Firstly, biological differences may give rise to differences in the sense and need for power between men and women. Physical strength and high level of testosterone are linked with the need and motivation for power and domination (Schultheiss, Campbell, \& McClelland, 1999; Schultheiss, Dargel, \& Rhode, 2003; Schultheiss et al., 2005; Sellers, Mehl, \& Josephs, 2007). Secondly, the process of socialisation provides women with information on what is a stereotypical female behaviour and what is not (Brannon, 2002; Mandal, 2008). Since their earliest years, women are taught that because of their gender they will have less power, so they do have less power in the future, which may also account for lower sense of power among female superiors. Processes linked with the self-fulfilling prophecy (Rosenthal \& Jacobson, 1968) as well as stereotyping risk (Steele \& Aronson, 1995) may play an important role here.

The purpose of the study was to answer the question of whether the individual differences in the need for power and sense of power differentiate people in terms of their job position. Those differences could arise both from the individual differences that led some of the participants of the study to gain management positions, but may also result from the possession of power itself. Another purpose of the study was to determine the dependence of gender in the context of the need for power and sense of power and power in the professional environment.

\section{PARTICIPANTS AND PROCEDURE}

The study involved 205 participants: 107 women and 98 men, with a mean age of 42.14 years $(S D=11.73$ years). The group consisted of 100 individuals in managerial positions and 105 subordinates. The respondents had different occupations, for example: entrepreneur, electrician, teacher, office clerk, shop assistant, salesperson, administrative worker, miner, economist, physician, psychologist, manager, white-collar worker, electronic engineer, nurse, cleaner, sales representative, and many others. The majority of participants $(65.00 \%, n=134)$ had a university degree. Most of the participants lived in towns and cities with a population of $10,000-500,000$ $(41.00 \%, n=84)$.

The study was carried out among employees of companies, firms, enterprises, and organisations in the Silesian and Mazovian provinces. It was conducted in an anonymous and voluntary manner. The sampling technique used for the study was purposive with respect to the occupied position (superiors and subordinates).

\section{MEASURES}

Need for Power. Index of Personal Reactions (Bennet, 1988; Polish adaptation of authors) is a tool that was designed to analyse the need for power and influence as personality traits. The factor analysis confirmed the distinction between nPower and nInfluence. The tool consists of four scales: Ability to Influence and Exercise Power (12 items, for example: I usually know how to get what I want); Need for Power (13 items, for example: I want to be a decision-making person); Need for Influence (eight items, for example: I like to feel that what I have to say has an influence on other people); and Resistance to Subordination (eight items, for example: I have difficulties accepting somebody's power [control] over me). The participants provided answers on a five-point scale ranging from 1 (does not describe me well) to 5 (describes me well). In this survey, the tools' reliability ranged from $\alpha=.75$ to $\alpha=.88$.

Sense of Power. The Personal Sense of Power (Anderson, John, \& Keltner, 2012; Polish adaptation by the authors; Mandal \& Kocur, 2015) is designed to measure personal sense of power. It consists of two parts. First, the examiner chooses the area (relation) that is to be evaluated. For instance: In my relation with others...; In my relation with my partner (in a close relationship)...; In my relation with my superior... or other. After the relationship has been determined, the subject of the study takes a stance on eight statements regarding various manifestations of power (e.g. I can make other people listen to what I have to say, or I can make others do what I want them to do). The participant provides answers on a scale of 1 (I strongly disagree) to 7 (I strongly agree). The higher the score, the stronger the sense of power. In this survey, the tool's reliability ranged from $\alpha=.67$ to $\alpha=.84$ (Anderson, John, \& Keltner, 2012).

Directiveness. The Directiveness Scale SD (Ray, 1976; Polish adaptation by Brzozowski, 1997) was compiled as part of the analysis of an authoritarian personality. It is utilised to examine directiveness construed as aggressive dominance, a tendency to impose one's will on others. The scale comes in two versions: complete (D-26), which consists of 26 ques- 
tions, and abridged (D-15), with 15 questions. In this study, an abridged version was used. Sample items include: Do you belong to the category of people who always like to have everything their own way? Do you have an inclination to dominate the conversation? The participants answer by choosing one of the three options (YES, ?, NO). A high score translates into a high level of directiveness. In this survey, the scale's reliability is satisfactory $(\alpha=.78)$.

Demographic and occupational data. This tool consists of two parts. The first one covers questions regarding sociodemographic features of the participants of the study. The second part concerns power within a professional organisation. It is implemented in order to define the position that the subject holds, his or her earnings, and the number of subordinates (in the case of participants occupying managerial positions).

\section{RESULTS}

\section{POWER IN MANAGERIAL POSITIONS}

Based on the results of the study, differences between people in positions of power and subordinated was observed. The superiors scored substantially higher on the following subscales: Ability to Influence and Exercise Power $(p<.001)$, Need for Power $(p<.001)$, Need for Influence $(p<.001)$, and Resistance to Subordination $(p=.029)$. The results are shown in Table 1 .

Furthermore, the analysis found discrepancies in terms of sense of power in different relations of superiors and subordinates. The former scored higher on sense of power in relations with other people $(p<.001)$, sense of power in relations with colleagues $(p<.001)$, and in relations with superiors $(p<.001)$. No significant statistical differences were observed with respect to sense of power in close romantic relationships $(p=.151)$. The results are shown in Table 2.

The study also revealed differences in terms of directiveness in superiors and subordinates. The superiors were characterised by a higher level of directiveness $(p<.001)$ than the subordinates. The results are shown in Table 3.

In the group of superiors, the study showed a correlation between the number of subordinates and the sense of ability to influence and exert power $(r=.28$; $p=.005)$, the need for influence, $(r=.27 ; p=.006)$, sense of power in relations with others $(r=.21$;

Table 1

Need for power and need for influence in superiors and subordinates

\begin{tabular}{|c|c|c|c|c|c|c|c|}
\hline \multirow[t]{2}{*}{ Variable } & \multicolumn{2}{|c|}{$\begin{array}{c}\text { Managerial } \\
\text { positions }\end{array}$} & \multicolumn{2}{|c|}{$\begin{array}{l}\text { Non-managerial } \\
\text { positions }\end{array}$} & \multirow[t]{2}{*}{$Z$} & \multirow[t]{2}{*}{$p$} & \multirow[t]{2}{*}{$r^{*}$} \\
\hline & $M$ & $S D$ & $M$ & $S D$ & & & \\
\hline $\begin{array}{l}\text { Ability to influence and } \\
\text { exercise power }\end{array}$ & 43.68 & 8.44 & 35.73 & 10.90 & -5.55 & $<.001$ & -.39 \\
\hline Need for power & 31.05 & 9.12 & 25.05 & 8.30 & -4.52 & $<.001$ & .32 \\
\hline Need for influence & 37.64 & 8.42 & 30.48 & 10.30 & -5.24 & $<.001$ & -.37 \\
\hline Resistance to subordination & 18.88 & 4.90 & 17.23 & 4.81 & -2.18 & .029 & -.15 \\
\hline
\end{tabular}

Table 2

Sense of power in different relations in superiors and subordinates

\begin{tabular}{|c|c|c|c|c|c|c|c|}
\hline \multirow[t]{2}{*}{ Variable } & \multicolumn{2}{|c|}{$\begin{array}{c}\text { Managerial } \\
\text { positions }\end{array}$} & \multicolumn{2}{|c|}{$\begin{array}{c}\text { Non-managerial } \\
\text { positions }\end{array}$} & \multirow[t]{2}{*}{$Z$} & \multirow[t]{2}{*}{$p$} & \multirow[t]{2}{*}{$r^{*}$} \\
\hline & $M$ & $S D$ & $M$ & $S D$ & & & \\
\hline $\begin{array}{l}\text { Sense of power in relations } \\
\text { with others }\end{array}$ & 41.40 & 6.59 & 37.52 & 6.67 & -4.01 & $<.001$ & -.28 \\
\hline $\begin{array}{l}\text { Sense of power in relations } \\
\text { with partners }\end{array}$ & 41.90 & 6.32 & 40.14 & 7.29 & -1.43 & .151 & -.10 \\
\hline $\begin{array}{l}\text { Sense of power in relations } \\
\text { with colleagues }\end{array}$ & 43.31 & 6.34 & 37.03 & 6.67 & -6.37 & $<.001$ & -.45 \\
\hline $\begin{array}{l}\text { Sense of power in relations } \\
\text { with superiors }\end{array}$ & 38.85 & 6.85 & 34.24 & 6.54 & -4.36 & $<.001$ & -.30 \\
\hline
\end{tabular}

Note. *Estimator of the effect size proposed by V. Glass. 
Table 3

Directiveness in superiors and subordinates

\begin{tabular}{|c|c|c|c|c|c|c|c|}
\hline & \multicolumn{2}{|c|}{$\begin{array}{c}\text { Managerial } \\
\text { positions }\end{array}$} & \multicolumn{2}{|c|}{$\begin{array}{c}\text { Non-managerial } \\
\text { positions }\end{array}$} & \multirow[t]{2}{*}{$Z$} & \multirow[t]{2}{*}{$p$} & \multirow[t]{2}{*}{$r^{*}$} \\
\hline & $M$ & $S D$ & $M$ & $S D$ & & & \\
\hline Directiveness & 34.87 & 8.40 & 29.27 & 5.76 & -4.88 & $<.001$ & .34 \\
\hline
\end{tabular}

Table 4

Correlations between the need for power, sense of power and directiveness, and the number of subordinates and earnings

\begin{tabular}{|c|c|c|c|c|}
\hline \multirow[t]{2}{*}{ Variable } & \multicolumn{2}{|c|}{$\begin{array}{l}\text { Number of subordinates } \\
\qquad(n=100)\end{array}$} & \multicolumn{2}{|c|}{$\begin{array}{l}\text { Earnings } \\
\left(n=168^{*}\right)\end{array}$} \\
\hline & $r$ & $p$ & $r$ & $p$ \\
\hline Ability to influence and exercise Power & .28 & .005 & .34 & $<.001$ \\
\hline Need for power & .14 & .158 & .28 & $<.001$ \\
\hline Need for influence & .27 & .006 & .32 & $<.001$ \\
\hline Resistance to subordination & -.07 & .465 & .11 & .157 \\
\hline Sense of power in relations with others & .21 & .037 & .31 & $<.001$ \\
\hline Sense of power in relations with a partner & .24 & .018 & .17 & .027 \\
\hline Sense of power in relations with colleagues & .11 & .284 & .37 & $<.001$ \\
\hline Sense of power in relations with superiors & .12 & .236 & .17 & .024 \\
\hline Directiveness & .04 & .697 & .34 & $<.001$ \\
\hline
\end{tabular}

Note. ${ }^{*} 168$ participants disclosed the amount of earnings.

$p=.037)$, and with a partner in a close relationship $(r=.24 ; p=.018)$.

The participants' earnings correlated positively with all the variables, with the exception of resistance to subordination $(r=.11 ; p=.157)$. The results are shown in Table 4.

Backward stepwise approach analysis was carried out on a variable number of subordinates as a result of which, relevant predictors were not obtained. Also, a forward stepwise approach analysis was carried out for the income variable. Two regression models were developed to explain the income variable for each group of predictors (sense of power, need for power). The for- ward stepwise approach was applied and the regression models obtained are presented in Table 5. Among the predictors expressing the sense of power, the sense of power in relations with other people was statistically relevant. Other predictors, due to statistically irrelevant growth of the aforesaid variation after they were added to the model, were not eventually included in the ultimate regression model. Among the predictors expressing the need for power, the ability to exert power and influence proved to be of statistical importance. Others, due to a statistically irrelevant growth of the discussed variation after their inclusion in the model, were not eventually included in the ultimate regression model.

Table 5

Backwards stepwise regression for income variable

\begin{tabular}{|c|c|c|c|c|c|}
\hline Predictors & $b^{*}$ & $t$ & $F$ & $d f$ & $R^{2}$ \\
\hline \multicolumn{6}{|l|}{ Sense of power in different relations } \\
\hline Sense of power in relations with others & .22 & $2.93^{* *}$ & $8.57^{* *}$ & 166 & .04 \\
\hline \multicolumn{6}{|l|}{ Need for power } \\
\hline $\begin{array}{l}\text { Sense of power in exerting power } \\
\text { and influence }\end{array}$ & .18 & $2.37^{*}$ & $5.63^{*}$ & 166 & .03 \\
\hline
\end{tabular}


Table 6

Managerial and non-managerial positions and gender

\begin{tabular}{|c|c|c|c|c|c|c|}
\hline \multirow[t]{2}{*}{ Gender } & \multicolumn{2}{|c|}{ Managerial positions } & \multicolumn{2}{|c|}{$\begin{array}{c}\text { Non-managerial } \\
\text { positions }\end{array}$} & \multirow[t]{2}{*}{$z$} & \multirow[t]{2}{*}{$p$} \\
\hline & $N$ & $\%$ & $N$ & $\%$ & & \\
\hline Males & 63 & 63.00 & 35 & 33.33 & 4.25 & $<.001$ \\
\hline Females & 37 & 37.00 & 70 & 66.67 & 4.25 & $<.001$ \\
\hline Total & 100 & 100.00 & 105 & 100.00 & & \\
\hline
\end{tabular}

Note. The $p$-values for one-tailed test.

Table 7

Comparison of women and men in terms of the number of subordinates and earnings

\begin{tabular}{|c|c|c|c|c|c|c|c|c|}
\hline \multirow[t]{2}{*}{ Variable } & \multicolumn{2}{|c|}{ Women } & \multicolumn{2}{|c|}{ Men } & \multirow[t]{2}{*}{$U$} & \multirow[t]{2}{*}{$Z$} & \multirow[t]{2}{*}{$p$} & \multirow[t]{2}{*}{$r^{*}$} \\
\hline & $M$ & $S D$ & $M$ & $S D$ & & & & \\
\hline $\begin{array}{l}\text { Number of subordinates } \\
(n=100)\end{array}$ & 9.35 & 7.12 & 39.51 & 83.01 & 657.00 & -3.63 & $<.001$ & -.36 \\
\hline $\begin{array}{l}\text { Participants' earnings } \\
(n=186)\end{array}$ & 3787 & 1917 & 7033 & 7203 & 468.50 & -3.27 & $<.001$ & -.26 \\
\hline $\begin{array}{l}\text { Earnings of people } \\
\text { in managerial positions } \\
(n=86)\end{array}$ & 5045 & 1851 & 8610 & 8170 & 2052.00 & -4.68 & $<.001$ & -.50 \\
\hline
\end{tabular}

\section{GENDER AND POWER IN THE WORKPLACE}

Significantly more males $(63.00 \%)$ occupied managerial positions than females (37.00\%), $p<.001$. The findings are shown in Table 6. On average, women had fewer subordinates $(M=9.35)$ than men $(M=39.51)$, $p<.001$. Furthermore, overall, women earned less $(M=3787$ PLN $)$ than men $(M=7033$ PLN $), p<.001$. The comparison between women and men holding leadership positions also confirmed lower women's incomes $(M=5045 \mathrm{PLN})$ in contrast to $(M=8610 \mathrm{PLN})$ those earned by male professionals, $p<.001$ (Table 7 ).
Women scored significantly higher on the sense of power in relations with other people $(p<.001)$, colleagues $(p<.001)$, and with superiors $(p=.002)$. Additionally, analysis was conducted solely among supervisors. In this case, no discrepancies were observed between men and women. Only on the statistical trend level did women score lower on the sense of power in relations with superiors $(U=906.50$, $Z=1.85, p=.064)$. The results are shown in Table 8 .

The conducted analyses revealed lower scores in women in terms of the sense of ability to influence and exert power $(p<.001)$, need for power

Table 8

Comparison of women and men in terms of subjective power in a professional organisation

\begin{tabular}{|c|c|c|c|c|c|c|c|c|}
\hline \multirow[t]{2}{*}{ Variable } & \multicolumn{2}{|c|}{ Women $(n=107)$} & \multicolumn{2}{|c|}{ Men $(n=98)$} & \multirow[t]{2}{*}{$U$} & \multirow[t]{2}{*}{$Z$} & \multirow[t]{2}{*}{$p$} & \multirow[t]{2}{*}{$r^{*}$} \\
\hline & $M$ & $S D$ & $M$ & $S D$ & & & & \\
\hline $\begin{array}{l}\text { Sense of power with other } \\
\text { people }\end{array}$ & 37.75 & 6.66 & 41.24 & 6.71 & 3708.50 & -3.62 & $<.001$ & -.25 \\
\hline $\begin{array}{l}\text { Sense of power in the } \\
\text { relation with partner }\end{array}$ & 40.55 & 6.93 & 41.49 & 6.82 & 4968.00 & -0.65 & .259 & -.05 \\
\hline $\begin{array}{l}\text { Sense of power with } \\
\text { colleagues }\end{array}$ & 38.66 & 6.76 & 41.65 & 7.41 & 3788.00 & -3.43 & $<.001$ & -.24 \\
\hline $\begin{array}{l}\text { Sense of power in the } \\
\text { relation with a superior }\end{array}$ & 35.08 & 6.18 & 38.02 & 7.66 & 4036.00 & -2.84 & .002 & -.20 \\
\hline
\end{tabular}

Note. The $p$-values for one-tailed test. ${ }^{*}$ Estimator of the effect size proposed by V. Glass. 
Dagna Kocur, Eugenia Mandal

Table 9

Comparison of men and women with respect to personal power determinants

\begin{tabular}{|c|c|c|c|c|c|c|c|c|}
\hline \multirow[t]{2}{*}{ Variable } & \multicolumn{2}{|c|}{$\begin{array}{l}\text { Women } \\
(n=107)\end{array}$} & \multicolumn{2}{|c|}{$\begin{array}{c}\text { Men } \\
(n=98)\end{array}$} & \multirow[t]{2}{*}{$U$} & \multirow[t]{2}{*}{$Z$} & \multirow[t]{2}{*}{$p$} & \multirow[t]{2}{*}{$r^{*}$} \\
\hline & $M$ & $S D$ & $M$ & $S D$ & & & & \\
\hline $\begin{array}{l}\text { Ability to influence and } \\
\text { exercise power }\end{array}$ & 36.64 & 10.71 & 42.86 & 9.37 & 3378.00 & -4.40 & $<.001$ & -.31 \\
\hline Need for power & 26.63 & 9.14 & 29.45 & 9.07 & 4295.00 & -2.23 & .013 & -.16 \\
\hline Need for influence & 32.37 & 10.55 & 35.71 & 9.27 & 4211.50 & -2.43 & .008 & -.17 \\
\hline Resistance to subordination & 17.78 & 4.73 & 18.32 & 5.11 & 4822.50 & -0.99 & .161 & -.07 \\
\hline Directiveness & 29.89 & 8.06 & 34.31 & 6.69 & 3552.00 & -3.98 & $<.001$ & -.28 \\
\hline
\end{tabular}

Note. The $p$-values for one-tailed test. *Estimator of the effect size proposed by V. Glass.

( $p=.013)$, need to influence $(p=.008)$, and directiveness $(p<.001)$ (Table 9$)$. In the group of superiors, no differences between women and men were observed.

For a more exact analysis of results, a two-factor analysis of gender variations was carried out as well as the position, where the dependent variables included the sense and need for power. The occupied position in the place of work proved to be the factor differentiating the level of six variables: sense of power in relations with others, in relations with colleagues, in relations with superiors, need for power, need for influence, and objection towards subordination. The gender only differentiated the level of two variables: the sense of power in relations with others and the sense of having influence and exerting power. The effects of interaction of both factors (gender and occupied position) proved to be statistically irrelevant. The results are presented in Table 10.

\section{DISCUSSION}

The conducted studies demonstrated that superiors scored significantly higher with respect to the need for power and influence, as well as directiveness. Such a result may be both the reason and the consequence of possessing power in a professional environment. Firstly, power changes people on cognitive, behavioural, and social levels (cf. Fiske, 1993; Galinsky, Gruenfeld, \& Magge, 2003; Wojciszke \& Strużyńska-Kujałowicz, 2007; Mandal, 2007; Mandal, 2008; Galinsky et al., 2006, 2008). For individuals occupying managerial positions the need for power may intensify. Secondly, those who gain power are characterised, among others, by a greater level of stereotypical masculinity (Lord, de Vader, \& Aliger, 1986) and domination (Judge et al., 2002; Judge, Colbert, \& Ilies, 2004), which are directly connected with the need for power and directiveness. Research by Donhauser, Rösch, and Schultheiss (2015), on the interdependency between implicit nPower and the ability to identify emotions, showed that people with a greater need for power are better able to recognise emotions on the basis of facial expressions. Those findings suggest that one of the means that allow people exhibiting a strong need for power to obtain a high social position may be connected with their heightened sensitivity to emotional signals in their social environment.

The results showed that superiors scored higher in terms of sense of power in relations with others, sense of power in relations with colleagues, and also in relations with superiors. Such a result may arise from the objective perception of their position in the social hierarchy or the metamorphic effects of power (Kipnis, 1972, 1976). It may also be the consequence of the individuals' original perception of the power they actually possess. This conviction of possession of power may have an impact on the way they influence other people, independently of their position within the society structures and in parallel with it. Individuals who perceive themselves as people who are in power behave in a more effective manner, thus increasing their actual authority (Bandura, 1999; Bugental \& Lewis, 1999; Mowday, 1978).

The study demonstrated that among the superiors there is a link between the number of subordinates and the sense of ability to influence and exert power and the need for influence. The results are similar to the research conducted by Karoly Varga (1975) concerned with the need for power and influence in scientists and engineers in the context of failed and successfully carried out scientific projects in the fields of pharmacy and chemistry. The study showed that the need for influence was strongly correlated with technical and economic success. The need for power was linked with both those types of success as well, but only when it occurred jointly with the need for influence. The need for power itself was connected with more frequent failures. Therefore, a larger number of subordinates observed among superiors who exhibit a greater need for influence may be accounted for by their increased efficiency. 
Table 10

Analysis of variance $(2 \times 2)$ for variables concerning power in considerations of the gender and position in the place of work factors

\begin{tabular}{|c|c|c|c|c|}
\hline & SS & $F$ & $p$ & $\eta_{p}{ }^{2}$ \\
\hline \multicolumn{5}{|l|}{ Sense of power in relations with others } \\
\hline Gender & 306 & 7.14 & .008 & .03 \\
\hline Position & 451.70 & 10.54 & $<.001$ & .05 \\
\hline Interaction between the gender and position & 0.70 & 0.02 & .987 & .01 \\
\hline \multicolumn{5}{|l|}{ Sense of power in relations with the partner } \\
\hline Gender & 9.80 & 0.21 & .648 & .01 \\
\hline Position & 131 & 2.81 & .095 & .01 \\
\hline Interaction between the gender and position & 103 & 2.21 & .139 & .01 \\
\hline \multicolumn{5}{|l|}{ Sense of power in relations with colleagues } \\
\hline Gender & 70.70 & 1.68 & .197 & .01 \\
\hline Position & 1611.50 & 38.19 & $<.001$ & .16 \\
\hline Interaction between the gender and position & 50.40 & 1.20 & .276 & .01 \\
\hline \multicolumn{5}{|l|}{ Sense of power in relations with the superior } \\
\hline Gender & 137.70 & 3.11 & .079 & .02 \\
\hline Position & 800.30 & 18.07 & $<.001$ & .08 \\
\hline Interaction between the gender and position & 55.40 & 1.25 & .265 & .01 \\
\hline \multicolumn{5}{|l|}{ Ability to exert influence and power } \\
\hline Gender & 835.80 & 9.14 & .003 & .04 \\
\hline Position & 2041.70 & 22.32 & $<.001$ & .10 \\
\hline Interaction between the gender and position & 193.80 & 2.12 & .147 & .01 \\
\hline \multicolumn{5}{|l|}{ Need for power } \\
\hline Gender & 60.50 & 0.80 & .372 & $<.01$ \\
\hline Position & 1459.60 & 19.34 & $<.001$ & .09 \\
\hline Interaction between the gender and position & 171.60 & 2.27 & .133 & .01 \\
\hline \multicolumn{5}{|l|}{ Need for influence } \\
\hline Gender & 82.40 & 0.92 & .338 & .01 \\
\hline Position & 2117.40 & 23.72 & $<.001$ & .11 \\
\hline Interaction between the gender and position & 35.40 & 0.40 & .530 & $<.01$ \\
\hline \multicolumn{5}{|l|}{ Objection against subordination } \\
\hline Gender & 0.14 & 0.01 & .939 & $<.01$ \\
\hline Position & 123.35 & 5.19 & .024 & .03 \\
\hline Interaction between the gender and position & 2.81 & 0.12 & .732 & $<.01$ \\
\hline
\end{tabular}

Note. SS - sum of squares.

The participants' earnings correlated with the sense of power. Such a result may be indirectly accounted for by agency and self-evaluation. The findings of studies conducted by Agata Gąsiorowska (2014) point towards a link between an individual's wealth and her or his self-focus, agency, and self-es- teem. The participants' earnings correlated positively with the need for power and influence, as well as with directiveness. This may be accounted for by the link between activation of the concept of money and an enhanced agency, which is in turn correlated with a more egoistic attitude and a greater inclination to- 
wards dominance (Abele \& Wojciszke, 2007; Wojciszke, 2010).

Males held managerial positions more frequently than females. Women had fewer subordinates than men, and earned less than men even in leadership roles. These findings are proof of existence of the socalled glass ceiling. It should be noted, however, that Poland was ranked fourth on the list of EU countries where the gender pay gap between females and males is narrower (the biggest differences were observed in Estonia; furthermore, globally those discrepancies are even more marked than in the EU) (Eurostat, Gender pay gap statistics, data from March 2016).

In the conducted studies women scored significantly lower on the sense of power in general relations with other people, colleagues, and superiors. The results concerning the general sense of power (in relations with others) differ from the findings of research by Anderson, John, and Keltner (2012), where no dissimilarities between men and women were observed. Sense of power in the context of the working environment has not been a focus for extensive research. The findings on sense of power coincide with objective power on the professional level. A study by Hilary Lips (1985) on the perception of power in women and men and the perception of females and males as possessors of power has yielded compelling data. Both women and men (but men to a greater extent) more frequently perceived males as those who are in possession of power rather than females. One important factor might be social convictions. From an early age, as a result of socialisation, women learn that because of their gender they hold less power. This causes them to actually possess less power in the future. A relevant factor here may be the essential processes similar to a self-fulfilling prophecy (Rosenthal \& Jacobson, 1968) and a stereotype threat (Steele \& Aronson, 1995).

The results showed that in comparison with men women have a lower sense of power, need for power, influence, and directiveness (cf. Ray, 1976; Brzozowski, 1997). Stereotypical femininity and masculinity play important roles here. The theory of agency and community as personality orientations shows elements characteristic of both women and men. Agency is a positive element of the stereotype of masculinity, whereas communion is a positive element of the femininity stereotype (Wojciszke, 2010). Women scored lower than men on agency (Wojciszke \& Szlendak, 2010). However, agency is directly connected with the need for power, as well as with directiveness.

Further studies and analyses ought to be supplemented with information, which would determine the reason and the result of the connections between the possessed power in the professional context and the sense of power and the need for it. Are they the consequence of the possessed power, or are they primary in relation to it and it is due to them that an individual secured power on a professional level in the first place?

The findings on the sense of power in the professional environment may be implemented in occupational and organisational psychology, as well as for training aimed at increasing competence and qualifications and during therapy.

\section{CONCLUSIONS}

Superiors are characterised by a greater need for power, and a stronger sense of power and directiveness than subordinates.

Men hold managerial positions more frequently than women.

Male executives earn more and they are in charge of a greater number of subordinates than female supervisors.

Women score higher on the need for power and sense of power, as well as on directiveness.

Incomes of women and men correlate positively with need for and sense of power.

\section{REFERENCES}

Abele, A. E., \& Wojciszke, B. (2007). Agency and communion from the perspective of self versus others. Journal of Personality and Social Psychology, 93, 751-763.

Anderson, C., John, O. P., \& Keltner, D. (2012). The personal sense of power. Journal of Personality, 80 , 313-344.

Bandura, A. (1999). Social cognitive theory of personality. In L. A. Pervin \& O. P. John (Eds.), Handbook of Personality: Theory and Research (pp. 154-196). New York: Guilford Press.

Bell, D. V. (1975). Power, influence, and authority: An essay in political linguistics. Oxford: University Press.

Bennett, J. B. (1988). Power and influence as distinct personality traits: development and validation of a psychometric measure. Journal of Research in Personality, 22, 361-394.

Brannon, L. (1999). Gender: psychological perspectives. New York, London: Taylor \& Francis.

Brzozowski, P. (1997). Skala Dyrektywności Johna J. Raya [Scale of Directiveness by John J. Ray]. Warszawa: Pracownia Testów Psychologicznych.

Bugental, D. B., \& Lewis, J. C. (1999). The paradoxical misuse of power by those who see themselves as powerless: How does it happen? Journal of Social Issues, 55, 51-64.

Donhauser, P. W., Rösch, A. G., \& Schultheiss, O. C. (2015). The implicit need for power predicts recognition speed for dynamic changes in facial expressions of emotion. Motivation and Emotion, 39, 714-721. 
Fiske, S. T. (1993). Controlling other people. The impact of power on stereotyping. American Psychologist, 48, 621-628.

French, J. R. P., Jr., \& Raven, B. (1959). The bases of social power. In D. Cartwright (Ed.). Studies in Social Power (pp. 150-169). Ann Arbor, MI: University of Michigan.

Galinsky, A. D., Magee, J. C., Gruenfeld, D. H., Whitson, J. A., \& Liljenquist, K. A. (2008). Power reduces the press of the situation: implications for creativity, conformity, and dissonance. Journal of Personality and Social Psychology, 95, 1450-1466.

Galinsky, A. D., Magee, J. C., Inesi, M. E., \& Gruenfeld, D. H. (2006). Power and perspectives not taken. Psychological Science, 17, 1068-1074.

Galinsky, A. D., Gruenfeld, D. H., \& Magge, J. C. (2003). From power to action. Journal of Personality and Social Psychology, 85, 453-466.

Gąsiorowska, A. (2014). Psychologiczne znaczenie pieniędzy. Dlaczego pieniądze wywotuja koncentracje na sobie? [Psychological meaning of money. Why money leads to self-focus?]. Warszawa: Wydawnictwo Naukowe PWN.

Judge, T. A., Bono, J. E., Ilies, R., \& Gerhardt, M. W. (2002). Personality and leadership: a qualitative and quantitative review. Journal of Applied Psychology, 87, 765-780.

Judge, T. A., Colbert, A. E., \& Ilies, R. (2004). A meta-analysis of the relationship between intelligence and leadership. Journal of Applied Psychology, 89, 542-552.

Kipnis, D. (1972). Does power corrupt? Journal of Personality and Social Psychology, 24, 33-41.

Kipnis, D. (1976). The Powerholders. Chicago: University Press.

Lips, H. M. (1985). Gender and the sense of power: Where are we and where are we going? International Journal of Women's Studies, 8, 483-489.

Lord, R. G., De Vader, C., \& Alliger, G. M. (1986). A meta-analysis of the relation between personality traits and leadership perceptions: an application of validity generalization procedures. Journal of Applied Psychology, 71, 402-410.

Mandal, E. (1995). Seksizm a praca i bezrobocie kobiet [Sexism and female employment and unemployment]. Psychologia Wychowawcza, 38, 235-240.

Mandal, E. (2007). Kobiety i mężczyźni a władza w organizacji [Women and men and power within an organization]. Kolokwia Psychologiczne (Psychological Colloquia), 16, 153-174.

Mandal, E. (2008). Mitość, wtadza i manipulacja w bliskich zwiqzkach [Love, power and manipulation in close relationships]. Warszawa: Wydawnictwo Naukowe PWN.

Mandal, E., \& Kocur, D. (2015). Poczucie władzy a poczucie satysfakcji seksualnej w intymnych relacjach [Sense of power and sexual satisfaction in intimate relationships]. Seksuologia Polska, 13, 1-7.
Minton, H. L. (1972). Power and personality. In J. T. Tedeschi (Ed.), The Social Influence Process. Chicago: Aldine-Atherton.

Mowday, R. T. (1978). The exercise of upward influence in organizations. Administrative Science Quarterly, 23, 137-156.

Sedlak, K. (2014). Ogólnopolskie badanie wynagrodzeń [Polish nationwide compensation survey]. Kraków: Sedlak \& Sedlak.

Ray, J. J. (1976). Do authoritarians hold authoritarian attitudes? Human Relations, 29, 307-325.

Rosenthal, R., \& Jacobson, L. (1968). Pygmalion in the classroom. The Urban Review, 3, 16-20.

Saltzman, A. (1991). Trouble at the top. US News \& World Report, 17, 40-48.

Schultheiss, O. C., Campbell, K. L., \& McClelland, D. C. (1999). Implicit power motivation moderates men's testosterone responses to imagined and real dominance successes. Hormones and Behavior, 36, 234-241.

Schultheiss, O. C., Dargel, A., \& Rhode, W. (2003). Implicit motives and gonadal steroid hormones: eVects of menstrual cycle phase, oral contraceptive use, and relationship status. Hormones and Behavior, 43, 293-301.

Schultheiss, O. C., Wirth, M. M., Torges, C. M., Pang, J. S., Villacorta, M. A., \& Welsh, K. M. (2005). Effects of implicit power motivation on men's and women's implicit learning and testosterone changes after social victory or defeat. Journal of Personality and Social Psychology, 88, 174.

Sellers, J. G., Mehl, M. R., \& Josephs, R. A. (2007). Hormones and personality: testosterone as a marker of individual differences. Journal of Research in Personality, 41, 126-138.

Steele, C. M., \& Aronson, J. (1995). Stereotype threat and the intellectual test performance of African Americans. Journal of Personality and Social Psychology, 69, 797-811.

Thibaut, J. W., \& Kelley, H. H. (1959). The social psychology of groups. New York: Wiley.

Titkow, A. (2003). Szklany sufit: bariery i ograniczenia karier kobiet: monografia zjawiska [Glass ceiling: barriers and limitations in women's careers: a phenomenon monography]. Warszawa: Fundacja Instytutu Spraw Publicznych.

Varga, K. (1975). Achievement, Power and Effectiveness of Research and Development. Human Relations, 28, 571-590.

Wojciszke, B. (2010). Sprawczość i wspólnotowość [Agency and communion]. Gdańsk: GWP.

Wojciszke, B., \& Strużyńska-Kujałowicz, A. (2007). Power influences self-esteem. Social Cognition, 25, 472-494.

Wojciszke, B., \& Szlendak, M. A. (2010). Skale do pomiaru orientacji sprawczej i wspólnotowej [Scales measuring agency and communion]. Psychologia Spoteczna, 5, 57-70. 